\title{
Introduction: The Entangled Histories of Science and Capitalism
}

\author{
by Lukas Rieppel, * Eugenia Lean, ${ }^{\S}$ and William Deringer ${ }^{\#}$
}

\begin{abstract}
This volume revisits the mutually constitutive relationship between science and capitalism from the seventeenth century to the present day. Adopting a global approach, we reject the notion that either science or capitalism can be understood as stages of modernity that emerged in the West and subsequently engendered a "Great Divergence" with the rest of the world. Instead, both science and capitalism were historical institutions that arose in an imperial context of global exchange and whose entanglement has been continuously remade. Rather than seek to explain either the development of modern science as a product of economic forces or the divergence of capitalist economies as a result of technical innovation, we want to emphasize the knowledge work that has been a central feature of both modern science and capitalism across the globe.
\end{abstract}

This volume examines the relationship between two cultural institutions - science and capitalism - that have proven enormously powerful in shaping the modern world. Due to its considerable scope and significance, scholars in the history and social studies of science have debated the exact nature of that relationship at least since the 1930s and 1940s, if not before. To be sure, then, ours is a massive and complex topic, one whose elucidation far exceeds the scope of any one volume. It also admits of a seemingly endless number of interpretations. But we nonetheless believe it is well worth revisiting. That is the goal of this volume: to explore how, and the extent to which, science and capitalism have been entangled with one another-historically, epistemically, and materially.

* Department of History, Brown University, 79 Brown Street, Providence, RI 02912; lukas rieppel@brown.edu.

- \$ Department of East Asian Languages and Cultures, Columbia University, New York, NY 10027 ; ey12006@columbia.edu.

\# Program in Science, Technology, and Society, Massachusetts Institute of Technology, 77 Massachusetts Avenue, E51-188, Cambridge, MA 02139; deringer@mit.edu.

We would like to acknowledge Marwa El-Shakry, Kavita Sivaramakrishnan, and their students in the fall 2017 "Global History of Science Seminar," who generously provided feedback on this introduction. We would also like to thank the Osiris general editors, W. Patrick McCray and Suman Seth, for their extensive comments and valuable feedback on this introduction.

- 2018 by The History of Science Society. All rights reserved. 0369-7827/11/2018-0001\$10.00

OSIRIS 2018, $33: 1-24$ 
Not only are we convinced that exploring the science-capitalism nexus remains a worthwhile endeavor, but we also believe that now is a particularly opportune time to do so. For a start, recent developments within the world of science and technology have brought economic issues to the forefront of our discipline's attention. In a world full of biotech spin-offs, technology-transfer offices, and patented gene sequences, Robert K. Merton's classic account of the scientific community as one whose normative structure effectively insulates its members from the demands of the marketplace has come to seem increasingly out of touch. ${ }^{1}$ Indeed, some scholars have begun to suspect the very nature and authority of science itself may have undergone a foundational transformation. ${ }^{2}$ But while economists, business leaders, and politicians often celebrate these changes in the name of a brave new "innovation economy," scholars of science and technology studies have been more interested in asking how a supposedly objective and value-neutral process of knowledge making has contributed to the creation of a deeply stratified society. Judging from the rich literature on biopiracy and biocapitalism, agnotology and the social construction of ignorance, as well as the toxic effects of the chemical industry and the use and abuse of big data, it is clear that although the story is varied, complex, and context dependent, part of the answer must involve the role capital often plays in shaping the research priorities of scientists. ${ }^{3}$ These concerns have thus given rise to calls for a more inclusive and engaged debate about knowledge in a democratic society, one that actively questions who is and is not involved in decisions about what sorts of research should be conducted, who pays for that research, and who ultimately suffers or benefits as a result. ${ }^{4}$

While scholars of science and technology have increasingly turned their attention to political economy, the panic of 2008 and the ensuing global debt crisis have had a

\footnotetext{
${ }^{1}$ Robert K. Merton, "Science and Technology in a Democratic Order," J. Legal Polit. Sociol. 1 (1942): 115-26; Merton, The Sociology of Science: Theoretical and Empirical Investigations (Chicago, 1973).

2 See, e.g., Daniel Lee Kleinman and Steven P. Vallas, "Science, Capitalism, and the Rise of the 'Knowledge Worker': The Changing Structure of Knowledge Production in the United States," Theorv Soc. 30 (2001): 451-92, on 481. See also Kleinman, Impure Cultures: University Biology and the World of Commerce (Madison, Wis., 2003); Philip Mirowski, Science-Mart: Privatizing American Science (Cambridge, Mass., 2011); Elizabeth Popp Berman, Creating the Market University: How Academic Science Became an Economic Engine (Princeton, N.J., 2012); Steven Shapin, The Scientific Life: A Moral Historv of a Late Modern Vocation (Chicago, 2008).

${ }^{3}$ On biocapitalism and biopiracy, see Stefan Helmreich, "Blue-Green Capital, Biotechnological Circulation and an Oceanic Imaginary: A Critique of Biopolitical Economy," BioSocieties 2 (2007): 287 302; Jack Ralph Kloppenburg, First the Seed: The Political Economy of Plant Biotechnology, 14922000 (Cambridge, 1988); Londa Schiebinger, Plants and Empire: Colonial Bioprospecting in the Atlantic World (Cambridge, Mass., 2004); Vandana Shiva, Biopiracy: The Plunder of Nature and Knowledge (Boston, 1997); Kaushik Sunder Rajan, Biocapital: The Constitution of Postgenomic Life (Durham, N.C., 2006). On agnotology, see Naomi Oreskes and Erik M. Conway, Merchants of Doubt: How a Handful of Scientists Obscured the Truth on Issues from Tobacco Smoke to Global Warming (New York, 2010); Robert Proctor and Londa L. Schiebinger, eds., Agnotology: The Making and Unmaking of Ignorance (Stanford, Calif., 2008). On toxicity, see Michelle Murphy, Sick Building Syndrome and the Problem of Uncertainty: Environmental Politics, Technoscience, and Women Workers (Durham, N.C., 2006); Robert Proctor, Golden Holocaust: Origins of the Cigarette Catastrophe and the Case for Abolition (Berkeley and Los Angeles, 2011). On big data algorithms, see the 2017 volume of Osiris. For a broader critique of this history, see David F. Noble, America by Design: Science, Technology, and the Rise of Corporate Capitalism (New York, 1977).

${ }^{4}$ For classic accounts, see Donna Haraway, "Situated Knowledges: The Science Question in Feminism and the Privilege of Partial Perspective," Feminist Stud. 14 (1988): 575-99; Sandra G. Harding, Whose Science? Whose Knowledge? (Ithaca, N.Y., 1991).
} 
similar effect within history departments as well, contributing to a wave of enthusiasm for a new brand of economic history that is often described as the history of capitalism. To the extent that it can be meaningfully distinguished from labor, business, and economic history, the "new" history of capitalism attempts to bring the lessons of social and cultural history to bear on the development of the modern economy. For such a young subfield, it has already generated a great deal of enthusiasm, even garnering front-page coverage in the New York Times. ${ }^{5}$ Our aim in this volume is to take into account the lessons that have been learned from both of these historiographic traditions - the renewed attention to political economy among historians of science and technology as well as the new history of capitalism-leveraging insights from the past several decades of scholarship to revisit a classic debate about the way science and capitalism have mutually informed one another.

Before delving into the details, we want to acknowledge that we are far from the first to examine the productive but controversial relationship between these two institutions. Often, previous scholars leveraged one side of the science-capitalism dyad as an explanatory resource to account for the other. Early on, for example, Marxist historians characterized the emergence of science in early modern Europe as a direct by-product of concurrent transformations in the means of economic production. Boris Hessen articulated a particularly outspoken version of this claim when he explained the "social and economic roots of Newton's Principia" in explicitly materialist terms as early as 1931, whereas less than a decade later, Edgar Zilsel contended that modern science came into being when "the advance of early capitalistic society" broke down traditional class barriers between scholars and artisans. Others drew similar conclusions without invoking an explicitly Marxian logic, including the Austrian economist Joseph Schumpeter, who proclaimed that modern science was produced by "the spirit of rationalist individualism, the spirit generated by rising capitalism." More recently, Carolyn Merchant drew upon Zilsel's research to formulate a powerful feminist interpretation of the Scientific Revolution, arguing that Bacon's faith in science to give mankind "dominion" over a passive and feminine nature derived in part from capital's emergent domination of labor. ${ }^{6}$ Despite their various differences, what united all of these authors was a shared emphasis on the material base out of which modern science developed.

\footnotetext{
5 Jennifer Schuessler, “In History Departments, It's Up with Capitalism,” New York Times, 6 April 2013, A1. For an introduction to the "new" history of capitalism, see Sven Beckert and Christine Desan, American Capitalism: New Histories (New York, 2018); Beckert, "History of American Capitalism," in American History Now, ed. Eric Foner and Lisa McGirr (Philadelphia, 2011); Kenneth Lipartito, "Reassembling the Economic: New Departures in Historical Materialism," Amer. Hist. Rev. 121 (2016): 101-39; Seth Rockman, "What Makes the History of Capitalism Newsworthy?," J. Earlv Repub. 34 (2014): 439-66; Jeffrey Sklansky, "The Elusive Sovereign: New Intellectual and Social Histories of Capitalism," Mod. Int. Hist. 9 (2012): 233-48; Michael Zakim and Gary John Kornblith, eds., Capitalism Takes Command: The Social Transformation of Nineteenth-Century America (Chicago, 2012).

${ }^{6}$ Boris Hessen, "The Social and Economic Roots of Newton's Principia," in The Social and Economic Roots of the Scientific Revolution, ed. Gideon Freudenthal and Peter McLaughlin (Dordrecht, 2009), 41-101; Edgar Zilsel, The Social Origins of Modern Science, ed. Diederick Raven, Wolfgang Krohn, and R. S. Cohen (Dordrecht, 2000), 7; Joseph A. Schumpeter, Capitalism, Socialism, and Democracy (New York, 1942), 124; Carolyn Merchant, The Death of Nature: Women, Ecology and the Scientific Revolution (New York, 1980), chap. 7. See also J. D. Bernal, Science and Industry in the Nineteenth Century (London, 1953).
} 
Another classic approach tells a different story entirely, while maintaining a similar logical structure: rather than embed science within its economic context, this literature invokes science to help account for the rise of modern capitalism. Mid-twentiethcentury theorists of economic "modernization" like W. W. Rostow, for example, identified "the gradual evolution of modern science and the modern scientific attitude" as a decisive factor separating vibrant, capitalist economies from less dynamic predecessors and alternatives. The generation of knowledge through scientific inquiry enabled technological advances, increased productivity, and abetted the accumulation of capital, the argument went - all of which fueled the process and ethos of growth central to the promise of capitalism. Among the foremost voices for this view was Simon Kuznets, who wrote in 1966 that "one might define modern economic growth as the spread of a system of production . . . based on the increased application of science." Moreover, central to this notion of modernization was the idea that science originated in Europe and subsequently spread to the rest of the world through a process of "diffusion." "Thus, rather than locate the Scientific Revolution within the context of capitalism, this literature used it to explain the so-called Great Divergence between Europe and the rest of the world, about which we will have more to say in the pages that follow.

In contrast to both of these classic approaches, recent scholarship tends to frame the historical relationship between science and capitalism as a more nuanced and complex affair. Still, perhaps because of differing social and institutional networks stemming from distinct patterns in graduate training, it remains surprisingly rare to find truly symmetric analyses of the way these two institutions have developed in tandem. ${ }^{9}$ One of the main contributions we hope to make with this volume is thus simply to further integrate the history of science with the new history of capitalism. By emphasizing powerful points of synergy between the two fields, we would like to help generate a more robust conversation across the disciplinary divide. In addition, however, we do want to offer a few more substantive contributions as well. These contributions broadly fall into three clusters or categories. First, we want to stress that the most useful way to understand the historical relationship between science and capitalism does not privilege one or the other side of the dyad, attempting to parse out the unique causal or explanatory contributions of each. Rather, we feel that it is both more important and fruitful to examine the ways in which science and capitalism have been continually coproduced in a variety of contexts and time periods. Understanding the mutually constitutive entanglement of science and capitalism is an empirical project; the best way forward is to accumulate a diverse array of examples from which more specific themes, patterns, and trends may emerge over time.

\footnotetext{
${ }^{7}$ W. W. Rostow, “The Stages of Economic Growth," Econ. Hist. Rev. 2nd ser., 12 (1959): 1-16, on 4; more generally, Rostow, The Stages of Economic Growth: A Non-Communist Manifesto (Cambridge, 1962). Simon Kuznets, Economic Growth and Structure: Selected Essays (London, 1966), 84; also quoted in Joel Mokyr, "Innovation in Historical Perspective: Tales of Technology and Evolution," in Technological Innovation and Economic Performance, ed. Benn Steil, David G. Victor, and Richard R. Nelson (Princeton, N.J., 2002), 23-46, on 25. For a discussion of economic growth as the essence of capitalism, see Timothy Shenk, "Apostles of Growth," Nation, 5 November 2014.

${ }^{8}$ See George Basalla, "The Spread of Western Science," Science 156 (1967): 611-22.

${ }_{9}^{9}$ For some recent, and notable, exceptions, see Dan Bouk, How Our Davs Became Numbered (Chicago, 2015); Eli Cook, The Pricing of Progress: Economic Indicators and the Capitalization of American Life (Cambridge, Mass., 2017); Jamie L. Pietruska, Looking Forward: Prediction and Uncertaintv in Modern America (Chicago, 2017).
} 
Second, we worry that, perhaps because of its Marxian roots, scholarship on the way science and capitalism intersect often deploys a materialist ontology that downplays the importance of thinking. In contrast, we want to emphasize the role of cognitive practices such as theorizing, calculating, and so on, in both the history of science and capitalism. But we do not simply advocate a return to the history of ideas. Instead, we look to scholarship on the material culture of science for inspiration on how to break down the neat binary between thoughts and actions, words and things, representation and reality on which the Marxian distinction between base and superstructure ultimately relies. ${ }^{10}$ Texts, utterances, and other representational artifacts can thus be regarded as real things in the world, whereas ways of knowing can be seen as a form of cognitive labor. Not only should thinking, calculating, planning, forecasting, organizing, and theorizing all be afforded a central place in the history of capitalism, we contend, but these seemingly abstract and disembodied activities can and ought to be studied as genuine forms of practice with the power to produce far-reaching effects in surprisingly distant parts of the world. This makes it possible to denaturalize some of our culture's most authoritative knowledge claims - rendering both modern science and capitalism as a product of particular people with specific motivations informed by their local circumstances - without denying how solid and durable those knowledge claims often turn out to be. ${ }^{11}$

Last but not least, this volume seeks to challenge older assumptions about the spaces and places in which both science and capitalism developed. Here our aim is to do more than simply make evenhanded comparisons between different parts of the world. Instead, we want to insist that neither science nor capitalism can properly be said to have "originated" in any particular place whatsoever, geographic or otherwise. As a great deal of recent scholarship has been at pains to demonstrate, both institutions were continually produced and re-produced through a global process of circulation. Thus, in addition to moving beyond the laboratory and factory floor, this volume seeks to treat both science and capitalism as transregional, indeed global, phenomena. Further, in line with our desire to denaturalize both capitalist markets and scientific knowledge, we resist the temptation to treat either science or capitalism as a universal category, always and everywhere the same. Instead, both are historically contingent products of local practices. Of course, we do not deny that both have acquired considerable epistemic prestige and became geographically widespread. For that reason, much of this volume is geared to addressing the way science and capitalism rose to such power over the past several centuries, but without making teleological claims of

\footnotetext{
${ }^{10}$ The literature on new materialism is huge and getting bigger by the minute. In the history of science, we find the turn to study material culture especially useful. See, e.g., Peter Galison, Image and Logic: A Material Culture of Microphysics (Chicago, 1997); Hans-Jörg Rheinberger, Toward a History of Epistemic Things: Synthesizing Proteins in the Test Tube (Stanford, Calif., 1997); Pamela Smith, The Bodv of the Artisan: Art and Experience in the Scientific Revolution (Chicago, 2004).

${ }^{11}$ For more on the way scientific theorizing in particular can be studied as a form of cognitive practice, see, e.g., David Kaiser, Drawing Theories Apart: The Dispersion of Feynman Diagrams in Postwar Physics (Chicago, 2005); Hélène Mialet, Hawking Incorporated: Stephen Hawking and the Anthropology of the Knowing Subject (Chicago, 2012); Andrew Warwick, Masters of Theorv: Cambridge and the Rise of Mathematical Phvsics (Chicago, 2003). For an attempt to articulate a radically materialist metaphysics, see Gilles Deleuze and Félix Guattari, A Thousand Plateaus: Capitalism and Schizophrenia (Minneapolis, 1987); Graham Harman, Tool-Being: Heidegger and the Metaphysics of Objects (Chicago, 2002); Quentin Meillassoux, After Finitude: An Essay on the Necessity of Contingency (London, 2008).
} 
inherently progressive development (or regressive fall from grace, as the case may be). ${ }^{12}$

The rest of this introduction spells out these scholarly interventions in further detail. But first, one major caveat needs to be made explicit: because we regard science and capitalism as historical entities that are continually enacted in practice, we deliberately resist the temptation to offer a stable definition of either. Instead, we treat both as objects of empirical study. The point here is not to drain the key words in our title of their meaning, insisting that all knowledge is scientific or every economy capitalist. Rather, it is to treat both cultural institutions as historically constituted entities. That said, we do recognize several strands of similarity that create a kind of family resemblance between different ways the political economy of modern capitalism has been enacted and the epistemic ideals of modern science performed. For example, capitalist societies are often described as ones in which markets play a central role as the principal mechanism to coordinate between supply and demand. According to Karl Polanyi, rather than embed the marketplace within a broader set of cultural institutions, modern capitalism reframes all manner of social interactions as market transactions. ${ }^{13}$ For that reason, capitalist societies tend to regard individual liberty as sacrosanct. They also feature strong legal regimes to protect private property and to enforce contracts. Finally, capitalism extends the commodity-form to nearly all aspects of life, including "intellectual property." But Polanyi's emphasis on the cash nexus as a mechanism for coordinating the circulation of commodities is not the only way to understand what is specific about the political economy of modern capitalism. A different but equally longstanding tradition primarily regards capitalism as an engine for the accumulation of wealth. ${ }^{14}$ On this view, capitalism should be understood as a means to generate sustained growth by systematically using a portion of today's profits to fund tomorrow's productive enterprises. Money only becomes capital once it has been invested to expand the means of production. Insofar as it functions as a technology for shaping the future, capital thus confers immense social and political power. Moreover, absent a means of redistribution, capitalist economies tend to concentrate wealth and often produce high levels of inequality. To borrow Thomas Piketty's evocative phrase, in capitalism, "the past devours the future." ${ }^{15}$ But some-

\footnotetext{
${ }^{12}$ For an explicit defense of global history as an appropriate methodological framework for writing the history of capitalism, see, e.g., Sven Beckert, "Emancipation and Empire: Reconstructing the Worldwide Web of Cotton Production in the Age of the American Civil War," Amer. Hist. Rev. 109 (2004): 1405-38; Beckert, "From Tuskegee to Togo: The Problem of Freedom in the Empire of Cotton," J. Amer. Hist. 92 (2005): 498-526. For more on the importance of circulation to the history of science, see, e.g., Aileen Fyfe and Bernard Lightman, Science in the Marketplace: NineteenthCentury Sites and Experiences (Chicago, 2007); David N. Livingstone, Putting Science in Its Place: Geographies of Scientific Knowledge (Chicago, 2003); Kapil Rai. Relocating Modern Science: Circulation and the Construction of Knowledge in South Asia and Europe, 1650-1900 (Houndmills, 2007); James Secord, "Knowledge in Transit," Isis 95 (2004): 654-72.

${ }^{13}$ See Karl Polanyi, The Great Transformation (New York, 1944). On the question of valuation in particular, see also Patrik Aspers and Jens Beckert, "Value in Markets," in The Worth of Goods: Valuation and Pricing in the Economv (Oxford, 2011), 3-38. That said, the reduction to monetary value has hardly gone uncontested. For a particularly vivid example, see Viviana Zelizer, Morals and Markets: The Development of Life Insurance in the United States (New York, 1979).

${ }^{14}$ Karl Marx et al., Capital: A Critique of Political Economy, vol. 1 (London, 1992). For a more recent argument along these lines, see Fabian Muniesa, ed., Capitalization: A Cultural Guide (Paris, 2017).

15 Thomas Piketty, Capital in the Twenty-First Century, trans. Arthur Goldhammer (Cambridge, Mass., 2014), 571.
} 
thing similar holds true for science as well. Not only do ideas circulate, but they are also accumulated in "centers of calculation" such as museums, libraries, and all of the other institutions that collectively make up the epistemic infrastructure for knowledge production. ${ }^{16}$ Hence, scientific knowledge too is subject to both processes of circulation and acts of accumulation, which, in turn, helps to explain the uneven distribution of economic wealth and epistemic power. ${ }^{17}$

However we choose to describe the political economy of modern capitalism, one thing is certain: its roots run far deeper and its reach is far more expansive than the way we do business alone. Rather, capitalism may be likened to a Wittgensteinian "form of life," one that valorizes an impersonal, calculating sort of rationality as the cornerstone of sound judgement. Of course, modern science often makes similar claims for itself also, and it is widely invoked as both a model and litmus test of the right way to reason. ${ }^{18}$ Thus, while we deliberately eschew making normative claims about the correct way to demarcate the boundaries of either science or capitalism, we recognize that both categories have been invested with considerable normative power. Rather than engaging in boundary disputes about what truly constitutes science or distinguishes capitalism, this volume therefore includes a number of essays that explicitly ask how precisely these boundaries were policed and enacted in practice (Arunabh Ghosh's piece on "capitalist" vs. "communist" statistics during the mid-twentieth century and Julia Fein's essay on the commodification of specimens in Stalinist Russia perhaps being the clearest examples). ${ }^{19}$ Not seeking to ignore normative questions and controversies, we regard precisely these kinds of debates as especially fruitful objects of empirical investigation, because they help to illuminate how the changing relationship between science and capitalism was understood by specific people at particular times in history. ${ }^{20}$

The decision to treat science and capitalism as hotly contested but historically constituted categories also helps to delimit the chronological scope of this volume. Not only do science and capitalism both have a performative dimension, informing people's behavior while shaping the institutions that materially govern our lives, but, in a striking convergence, both also became objects of scholarly contemplation during the long nineteenth century. In each case, this happened as part of an effort to distinguish the right way to produce knowledge and the best way to organize a political economy. For example, whereas a number of words deriving from the Latin scientia have been used to characterize experiential knowledge of various kinds for hundreds of years,

${ }^{16}$ On "centers of calculation," see Bruno Latour, Science in Action (Cambridge, Mass., 1987). On the infrastructure of knowledge production more broadly, see Lorraine Daston, ed., Science in the Archives: Pasts, Presents, Futures (Chicago, 2017); Joanna Radin, Life on Ice: A Historv of New Uses for Cold Blood (Chicago, 2017).

See Jessica Ratcliff, "The Great Data Divergence: Global History of Science within Global Economic History," in Global Scientific Practice in an Age of Revolutions, 1750-1850, ed. Patrick Manning and Daniel Rood (Pittsburgh, 2016), 237-54.

${ }^{18}$ For a history of the "epistemic virtue" of objectivity in particular, see Lorraine Daston and Peter Galison, Objectivity (New York, 2007).

19 Arunabh Ghosh, "Lies, Damned Lies, and (Bourgeois) Statistics: Ascertaining Social Fact in Midcentury China and the Soviet Union"; Julia Fein, "Scientific Crude' for Currency: Prospecting for Specimens in Stalin's Siberia," both in this volume.

${ }^{20}$ For more on this approach, see Thomas Gieryn, "Boundary-Work and the Demarcation of Science from Non-Science," Amer. Sociol. Rev. 48 (1983): 781-95; Gieryn, Cultural Boundaries of Science: Credibility on the Line (Chicago, 1999). 
there was no such thing as the "scientific method" (or the professional scientist, for that matter) until historians and philosophers such as William Whewell began speculating about the best way to generate reliable knowledge. It was thus in a highly prescriptive context that the notion of science as detailed and factual knowledge produced through an objective process of rigorous hypothesis testing arose. ${ }^{21}$ The case of "capitalism" is even more clear. Although the word "capital" had long been used to denote assets, money, or commodities more broadly and "capitalist" as anyone who dealt in or otherwise had access to capital, the neologism "capitalism" was deliberately coined by mid-nineteenth-century radicals such as Proudhon and Marx to criticize a form of social organization they viewed as ruthless, unjust, and ultimately unstable. Before long, the word "capitalism" came into much wider use to describe a distinctly modern political economy in which a calculative acquisitiveness informed more and more everyday decision making. ${ }^{22}$ To borrow terminology from Hallam Stevens's essay in this volume, both science and capitalism may therefore be said to constitute a performance that takes place on the stage of everyday life: to be a scientist or a capitalist is to perform a particular role in society. ${ }^{23}$ And such performances only became possible once an appropriate "script" was available. For example, a large number of observers since Marx have pointed out that to be a capitalist is to be a particularly future-oriented cognitive agent, always projecting oneself into an imagined space where present investments may generate profits or incur losses. ${ }^{24}$ Because this mercantile practice of projecting oneself into an imagined future was transferred to the creation of large-scale industrial endeavors during the long nineteenth century, the bulk of the essays that make up this volume concern events and circumstances that range from that period to the present day.

Once science and capitalism became objects of knowledge, their histories were also subjected to intense scrutiny and debate. In another striking convergence, the origins of both were then traced back to sixteenth- and seventeenth-century Europe. As this happened, both categories became means for distinguishing between the ancient and modern, the developed and primitive, the West and the rest, meaning that a fairly provincial script was used to appraise the knowledge-making and wealth-generating performances of people outside nineteenth-century Europe. Given this fraught historiographic terrain, we would have been remiss in ignoring the relationship between

${ }^{21}$ Henry M. Cowles, "The Age of Methods: William Whewell, Charles Peirce, and Scientific Kinds," Isis 107 (2016): 722-37; Sydney Ross, "Scientist: The Story of a Word," Ann. Sci. 18 (1962): 65-85; Richard Yeo, Defining Science: William Whewell, Natural Knowledge and Public Debate in Early Victorian Britain (Cambridge, 2003).

${ }^{22}$ Werner Sombart, Der moderne Kapitalismus (Leipzig, 1902); Max Weber, Die protestantische Ethik, und der Geist des Kapitalismus (Tübingen, 1905). For a brief history of the word "capitalism," see the introduction to Jürgen Kocka, Capitalism: A Short History, trans. Jeremiah Riemer (Princeton, N.J., 2016). See also Kocka and Marcel van der Linden, eds., Capitalism: The Reemergence of a Historical Concept (London, 2016).

${ }^{23}$ See Hallam Stevens, "Starting up Biology in China: Performances of Life at BGI," in this volume; Erving Goffman, The Presentation of Self in Everyday Life (Garden City, N.Y., 1959); Richard Schechner, Performance Studies: An Introduction, 2nd ed. (New York, 2006). For an influential application of performance studies to the practice of science, see Stephen Hilgartner, Science on Stage: Expert Advice as Public Drama (Stanford, Calif., 2000).

${ }_{24}$ Jens Beckert, Imagined Futures: Fictional Expectations and Capitalist Dynamics (Cambridge, Mass., 2016), 1-2. For a similar kind of analysis, see Jonathan Levy, "Capital as Process and the History of Capitalism," Bus. Hist. Rev. 91 (2017): 483-510; Fabian Muniesa, ed., Capitalization: A Cultural Guide (Paris, 2017). Finally, see also Cook, The Pricing of Progress (cit. n. 9). 
knowledge and commerce in other places and time periods. For that reason, we have also made sure to include a number of essays that cover events and developments prior to the nineteenth century and outside of Europe, without thereby seeking to produce an origin story for either science or capitalism. Instead, our aim is to show how epistemic and commercial values - matters of fact and matters of exchange - intersected in other time periods and geographies also. What is more, several of the essays that follow go further and adopt an explicitly transnational focus, showing how knowledge and profits were both generated through encounters and interactions between people from different parts of the globe.

Finally, we would like to zoom out somewhat to discuss the organization of our table of contents as a whole. This volume begins with a wide-ranging historiographical think piece from Harold J. Cook, which we intend as a "companion piece" to this introduction. ${ }^{25}$ Next, we have chosen to group the rest of this volume's essays according to the different kinds of entanglements they most clearly address as a way to highlight the centrality of the entanglement concept to our way of thinking. Of course, it goes without saying that each of these essays speaks to more than just one kind of entanglement. Hence, they could have been organized into different clusters as well. Nonetheless, we do hope the organization of our table of contents will prove both interesting and illuminating to readers. The first of these clusters consists of three essays that, in one way or another, discuss the cognitive and manual labor that is required to not only create but also maintain the various kinds of infrastructures that support the entanglement between science and capitalism. The second cluster groups together three essays that all deal with a particular kind of knowledge work (indeed, what may be the most iconic and well-known kind of knowledge work) that has shaped the way economic transactions are carried out: calculation. Third, there is a larger cluster of five essays that all address how the entangled histories of science and capitalism have helped to give rise to new kinds of objects, entities, or relationships in the world, ranging from the Comstock Lode to the accident-prone driver, among several others. Finally, there is another cluster of three essays that all foreground the transnational entanglement between science and capitalism, connecting events, people, and processes in Europe and North America with Asia. We hope the contributions will help strengthen the volume's three principal scholarly interventions, each of which are discussed in more detail next.

\section{DIVERGENCE AND ENTANGLEMENT}

Whereas this volume deliberately eschews the question of when science truly began, or how capitalism really got started, others often invoke the rise of modern science to explain the so-called Great Divergence (or "Enrichment") that took place between Europe and the rest of the world during the long nineteenth century. Economic historians drawing upon the work of Douglass C. North, for example, emphasize the significance of formal and informal institutions in creating the conditions for growth and prosperity. Besides the creation of a strong system of private property law, a habit of plain dealing, and a valorization of thrift, these historians often cite a love of learn-

\footnotetext{
${ }^{25}$ Harold J. Cook, "Sciences and Economies in the Scientific Revolution: Concepts, Materials, and Commensurable Fragments," in this volume.
} 
ing, a unique openness to useful ideas, and a constant desire to devise better ways of getting things done as direct contributions to the creation of modern capitalism. ${ }^{26}$ One of the most strident articulations of such an argument is by Joel Mokyr, who attributes the disproportionate economic success of Europe and North America to their exceptional culture. As recently as 2016, Mokyr argued that it was technological innovation that primarily fueled the Great Divergence: "the explosion of technological progress in the West was made possible by cultural changes," he contends, which "affected technology both directly, by changing attitudes toward the natural world, and indirectly, by creating and nurturing institutions that stimulated and supported the accumulation and diffusion of 'useful knowledge.' ${ }^{27}$ For a number of complex and interrelated reasons that included a faith in progress and concomitant irreverence for the wisdom of ancients, these cultural changes took place in Europe. As a result, it was Europe (as well as its former colonies in North America) that diverged from the rest of the world. ${ }^{28}$

The notion that uniquely Western cultural innovations were primarily responsible for the Great Divergence has not escaped criticism, however. For example, economic historians informed by world systems theory have tried to "reorient" both economic and world history to demonstrate the crucial role of non-Western societies in the making of the early modern and modern world. ${ }^{29}$ By establishing Asia as one of many centers in the early modern global economy, they effectively provincialize narratives of the European miracle and Western exceptionalism in the history of capitalism. ${ }^{30}$ But these histories remain fundamentally comparative in their approach, and one can even detect the specter of civilizational comparisons in some attempts to identify

\footnotetext{
${ }^{26}$ See, e.g., Stephen H. Haber et al., eds., Political Institutions and Financial Development (Stanford, Calif., 2008); Deirdre N. McCloskey, Bourgeois Equality: How Ideas, Not Capital or Institutions, Enriched the World (Chicago, 2016); McCloskey, Bourgeois Dignity: Why Economics Can't Explain the Modern World (Chicago, 2010); Douglass C. North, "Institutions," J. Econ. Perspect. 5 (1991): 97-112; North, "Institutions, Ideology, and Economic Performance," Cato J. 11 (1992): 477-96; North, Understanding the Process of Economic Change (Princeton, N.J., 2005): North. John Joseph Wallis, and Barry R. Weingast. "A Conceptual Framework for Interpreting Recorded Human History” (working paper, National Bureau of Economic Research, 2006).

${ }^{27}$ Joel Mokyr, A Culture of Growth: The Origins of the Modern Economy (Princeton, N.J., 2016), 7.

${ }^{28}$ See also Joel Mokyr, The Gifts of Athena: The Historical Origins of the Knowledge Economy (Princeton, N.J., 2002); Margaret C. Jacob and Larry Stewart, Practical Matter: Newton's Science in the Service of Industry and Empire (Cambridge, Mass., 2004); Mokyr, The Enlightened Economy: An Economic History of Britain 1700-1850 (New Haven, Conn., 2009); Jacob, The First Knowledge Economy: Human Capital and the European Economy, 1750-1850 (Cambridge, 2014). For a recent review of economic and economic-historical literature on this subject, see Cormac Ó Gráda, "Did Science Cause the Industrial Revolution?," J. Econ. Lit. 54 (2016): 224-39.

${ }^{29}$ Key scholars associated with this approach include Janet Abu-Lughod, Before European Hegemony: The World System A.D. 1250-1350 (Oxford, 1991); Andre Gunder Frank, ReOrient: Global Economy in the Asian Age (Berkeley and Los Angeles, 1998); Kenneth Pomeranz, The Great Divergence: China, Europe and the Making of the Modern World Economy (Princeton, N.J., 2000), among others. For more on the world systems theory approach to global inequality, see Daniel Chirot and Thomas D. Hall, "World-System Theory," Annu. Rev. Sociol. 8 (1982): 81-106; Immanuel Maurice Wallerstein, The Modern World-System, 4 vols. (Berkeley and Los Angeles, 2011); Wallerstein, The Essential Wallerstein (New York, 2000).

${ }^{30}$ Pomeranz, The Great Divergence (cit. n. 29) may be the most influential study to make this argument. Others include Roy Bin Wong, China Transformed: Historical Chang and the Limits of European Experience (Ithaca, N.Y., 1997). See also Richard von Glahn, Fountain of Fortune: Money and Monetary Policy in China, 1000-1700 (Berkeley and Los Angeles, 1996), which demonstrates late Ming China's massive appetite for imported silver from the Americas and its far-reaching consequences for the globalization of the early modern world economy.
} 
an Asian age as an alternative to Euro-American versions of capitalism and industrialization. ${ }^{31}$ As such, many world systems theorists cannot be said to fully reject the fundamental units of analysis - the "West" and the "rest"- that underlie triumphalist accounts of European exceptionalism. Finally, while there is no denying that many areas of Europe and North America became far richer and more commercially powerful than other parts of the world during the past three or four centuries, narratives of divergence tend to pay less attention to the way global capitalism was continually being made and remade after the point of divergence. ${ }^{32}$ Ironically, insofar as they neglect non-Western players as active agents in the global economy after the point of divergence, these narratives fail to account for the dynamic and truly global character of modern capitalism during all periods of its development.

A more recent critique of the Great Divergence argument has been articulated by historians of capitalism who insist that slavery, imperialism, and other means of coercive value extraction must be placed at the center of any narrative about the phenomenal enrichment of Europe and North America between the seventeenth and late nineteenth centuries. ${ }^{33}$ In his recent book on the worldwide web of cotton production, for example, Sven Beckert coins the term "war capitalism" to describe the forceful extraction and transfer of wealth from Asia, Africa, and the Americas that took place during Europe's "Age of Exploration." In so doing, he explicitly emphasizes the extent to which violence, coercion, and political power were leveraged to build the material infrastructure upon which free trade ideology has been erected. ${ }^{34}$ In this view, the Great Divergence resulted not so much from an explosion in technical know-how as from a willingness on the part of Europe's imperial powers to bring their warmaking capacities to bear on extracting and channeling the world's productive resources to fuel their own economic development. Although this line of argument does share some family resemblances with world systems theory, it avoids many of the pitfalls that plague the comparative method by adopting a more truly transnational approach. Moreover, historians of capitalism also depart from world systems theory in their tendency to foreground particular choices made by individual people working in concert to further their interests over structural analyses of how the West came to dominate the rest of the world.

The claim that modern capitalism was built on a foundation of imperial exploitation, military expropriation, and coerced labor offers a welcome corrective to the triumphalist narrative in which technological innovation primarily fueled economic

\footnotetext{
${ }^{31}$ For a study that seeks to reverse the comparative asymmetry in examining early modern world economic development, see Wong, China Transformed (cit. n. 30). For a book that takes extra care to choose comparable units of economic development for purposes of comparing world economic change, see Pomeranz, The Great Divergence (cit. n. 29).

${ }_{32}$ Pomeranz, The Great Divergence (cit. n. 29), for example, jumps at the end of the study from the point of "divergence" during the eighteenth century to the twenty-first century, when Asian global economic dominance once again seems impossible to deny.

${ }^{33}$ For more on the argument that slavery drove the development of North American capitalism in particular, see, e.g., Edward E. Baptist, The Half Has Never Been Told: Slavery and the Making of American Capitalism (New York, 2014); Sven Beckert and Seth Rockman, eds., Slaverv's Capitalism: A New Historv of American Economic Development (Philadelphia, 2016); Walter Johnson, River of Dark Dreams: Slavery and Empire in the Cotton Kingdom (Cambridge, Mass., 2013); Peter Linebaugh and Marcus Rediker, The Many-Headed Hydra: Sailors, Slaves, Commoners, and the Hidden History of the Revolutionary Atlantic (Boston, 2000).

${ }^{34}$ Sven Beckert, Empire of Cotton: A Global History (New York, 2014).
} 
growth. But one might nonetheless worry that revisionist accounts go too far in writing the history of science and technology out of the story altogether. Kenneth Pomeranz, for example, makes the counterfactual claim that if China had access to the same resources as the West, the Great Divergence might not have occurred. But this line of reasoning neglects what one scholar refers to as the "human factor," which gave rise to a shift from appreciating coal as a resource upholding livelihood-a principal goal of imperial statecraft during the late Qing Empire - to regarding it as a necessary fuel for survival in an industrial world order. ${ }^{35}$ Perhaps even worse is that a failure to address knowledge production leaves the history of capitalism vulnerable to the counterfactual claim that absent the prevalence of coerced labor and imperial expropriation, the Great Divergence would have still taken place. ${ }^{36}$

Ultimately, Great Divergence narratives largely ignore the degree to which science, capitalism, and imperialism all coproduced one another. As a great deal of work in the history of science makes abundantly clear, there is no separating imperial expansion and commercial motives on the one hand from the production of useful knowledge on the other. ${ }^{37}$ For example, Harold Cook's influential account of the Dutch East India Company's scientific work convincingly demonstrates that without taking the "activities of commerce, including the trading ventures once called voyages of discovery" into account, it would be very difficult to answer the deceptively obvious question of why such "an enormous amount of personal time and effort, and economic and other resources, come to be devoted to seeking out and acquiring precise and accurate descriptive information about natural things. " ${ }^{38}$ Thus, even if it were possible to eliminate imperialism from European history conceptually, there is no reason to suspect that the institutions responsible for the growth of both modern science and the production of new technologies would remain unchanged. Given how closely the practice of science and imperial statecraft were bound up with one another, it is impossible to maintain that one, not the other, must be afforded a primary causal role in explaining the Great Divergence.

It is for precisely that reason that we favor the idiom of entanglement, which has previously been put to powerful use by scholars such as Michelle Murphy, who draws upon it to explain the complicated, transnational, and sometimes unsettling inter-

\footnotetext{
${ }^{35}$ See Shellen Wu, Empires of Coal: Fueling China's Entry into the Modern World Order, 18601920 (Stanford, Calif., 2015).

${ }^{36}$ See, e.g., Deirdre N. McCloskey, "The Industrial Revolution, 1780-1860: A Survey," in The Economic History of Britain since 1700, ed. Roderick Floud and Deirdre N. McCloskey (Cambridge, 1981), 242-70. The controversy has become especially fierce in debates about the importance of slavery to the historical development of American capitalism in particular. See, e.g., Alan L. Olmstead, review of The Half That Has Never Been Told, by Edward Baptist, J. Econ. Hist. 75 (2015): 91923. For an overview of the recent controversy, see Marc Parry, "Shackles and Dollars," Chronicle of Higher Education, 8 December 2016. For a methodological defense of the counterfactual method for apportioning causal power, see Tim De Mey and Erik Weber, "Explanation and Thought Experiments in History," Hist. \& Theorv 42 (2003): 28-38.

${ }^{37}$ See, e.g., Lucile Brockway, Science and Colonial Expansion: The Role of the British Royal Botanic Gardens (New York, 1979); Richard Drayton, Nature's Government: Science, Imperial Britain, and the "Improvement" of the World (New Haven, Conn., 2000); John Gascoigne, Science in the Service of Empire: Joseph Banks, the British State and the Uses of Science in the Age of Revolution (Cambridge, 1998); Lisbet Koerner, Linnaeus: Nature and Nation (Cambridge, Mass., 1999); Schiebinger, Plants and Empire (cit. n. 3).

${ }^{38}$ Harold John Cook, Matters of Exchange: Commerce, Medicine, and Science in the Dutch Golden Age (New Haven, Conn., 2007), 45, 6.
} 
actions between reproductive health efforts, feminist political movements, technoscience, capitalist enterprise, and American imperial ambitions in the 1970s and 1980 s. $^{39}$ Instead of trying to isolate direct causal influences, the idiom of entanglement highlights complicated circuits, unanticipated trajectories, and feedback loops. We argue that this idiom is particularly useful for exploring the interrelated development of both science and capitalism for at least three key reasons. First, entanglement emphasizes the complexity, contingency, and variety of relationships that make up the science-capitalism nexus. To think of science and capitalism as entangled is to suggest the futility of insisting that any one causal thread should have primacy over another. Instead, doing so highlights the fact that, when viewed in detail in specific contexts, the relationship between science and capitalism is highly convoluted and does not follow any single prescribed path or trajectory. As Murphy notes, such entanglements can be "uneasy," and their ramifications unpredictable. Second, entanglement also offers a way to think about the durability of science and capitalism by showing how they are often reinforced and strengthened through their interaction. As anyone who owns a pair of earbuds will know, tangles are not only complex but also intransigent. They tend not to untangle easily and thus can be hard to undo. Third, entanglement offers a useful way - a useful "topology," as Murphy puts it through which to think about the geographic spaces and scales across which science and capitalism interact. ${ }^{40}$ As the essays in this volume show, science and capitalism have often become wound together in distinctive and powerful ways within specific local settings. But the threads that feed into those local knottings are also part of networks and circuits that far transcend the local and can be truly global. Perhaps most important of all is that entanglement offers a useful idiom for thinking about science and capitalism as part of the same, larger assemblage. Thus, rather than attempting to parse out the relative importance or causal power of each, this volume instead wants to suggest that both derive their considerable power and significance from being so readily, and so often, conjoined.

\section{KNOWLEDGE WORK}

If this volume's first scholarly intervention involves a shift from narratives of divergence to ones that foreground entanglement, its second is to inquire into the cognitive labor - what we call "knowledge work" - that generated many of the nodes around which the history of science became so entangled with the history of capitalism. To do so, we want to foreground specific practices more so than general ideas-focusing on the routinized activities that constitute economic life and scientific inquiry, along with the material things through which those activities are conducted, the "know-how" that makes them possible, the institutions and mores that structure them,

\footnotetext{
${ }^{39}$ Michelle Murphy, Seizing the Means of Reproduction: Entanglements of Feminism, Health, and Technoscience (Durham, N.C., 2012). There is also a rich anthropological literature on entanglement, notably as a way to theorize the interactions between different cultural groups (e.g., Western and nonWestern groups in colonial encounters) and between human social life and the material world. See Nicholas Thomas, Entangled Objects: Exchange, Material Culture, and Colonialism in the Pacific (Cambridge, Mass., 1991); Ian Hodder, "Human-Thing Entanglement: Towards an Integrated Archaeological Perspective," J. Rov. Anthropol. Inst. 17 (2011): 154-77; Hodder, Entangled: An Archaeology of the Relationship between Humans and Things (Malden, Mass., 2012).

${ }_{40}$ Murphy, Seizing the Means (cit. n. 39), 11-21.
} 
the emotions they elicit, and so on. ${ }^{41}$ Attention to practice has, of course, been one of the defining methodological trends in the history of science, especially since the 1990s, when scholars turned to the close examination of scientific practice as a way forward out of vexing disputes about the realism versus constructed-ness of scientific theories. Something similar is true for the history of capitalism as well. To no small degree, the history of capitalism and the history of science might therefore be written as histories of gerunds: managing, planning, measuring, calculating, predicting, experimenting, modeling, collecting, classifying, and so on, to name just a few. By studying these technical practices "in action," we can examine how seemingly natural, inevitable, or "black-boxed" aspects of economic order or scientific knowledge were in fact the product of local cultures, personal interests, contested choices, and historical contingencies. In a word, we want to focus attention on the intellectual labor through which science and capitalism were coproduced.

One broad realm of practice - one gerund - that offers an especially good opportunity for collaboration between historians of science and capitalism is, simply put, thinking. Among the most impressive achievements of the historiography of science has been the ability to show that scientific thinking does not simply proceed through individual inspiration or relentless methodicality but is rather diverse, disorderly, and surprising. Older histories of scientific ideas or scientific thought, understood as an accretion of static units of knowledge, have long since given way to an image of scientific thinking as a dynamic social and material process. By comparison, attention to the dynamism and complexity of economic thinking is of a somewhat more recent vintage. Dominant models of capitalism, both Marxist and neoclassical, long left relatively little room for thinking as an open-ended and generative activity and thus downplayed its significance as an object of social and economic analysis. In Marxist analyses, conscious acts of thinking have been seen as the expression of underlying material interests and the class consciousness they beget. In neoclassical models, the presumption is that all individuals, or at least those who move markets, act in ways that maximize their self-interest; what they "think" they are doing is far less important than what their economic choices reveal about their true preferences.

Yet recent scholarship, both in the new history of capitalism and in other fields like economic sociology and anthropology, has put thinking back at the center of capitalist action, showing that economic actors are "subjects" and that capitalism is, in a profound sense, an epistemic system. ${ }^{42}$ This effort to reopen the cognitive space of capitalism can be seen, for example, in the efforts of historians of capitalism to recover how foundational concepts in modern economic life — credit, risk, profit, the economy,

${ }^{41}$ For a discussion of the value of studying practice in the history of capitalism, see Kenneth Lipartito, "Connecting the Cultural and the Material in Business History," Enterprise Soc. 14 (2013): 686-704. The literature on scientific practice is certainly far too vast to do justice to here. Some especially influential examples include Andrew Pickering, ed., Science as Practice and Culture (Chicago, 1992); Robert Kohler, Lords of the Fly: Drosophila Genetics and the Experimental Life (Chicago, 1994); Pickering, The Mangle of Practice: Time. Agencv. and Science (Chicago, 1995); Galison, Image and Logic (cit. n. 10).

${ }^{42}$ On the importance of seeing economic actors as "not simple decision makers but also thinking subjects," see Hirokazu Miyazaki, Arbitraging Japan: Dreams of Capitalism at the End of Finance (Berkeley and Los Angeles, 2013), 6. On experimental systems and epistemic things, see Rheinberger, Toward a History (cit. n. 10). 
and so on - have been forged, refashioned, and made durable..$^{43}$ Or in the burgeoning attention historians, including many historians of science, have paid to the details of technical knowledge practices within business enterprises. ${ }^{44}$ Or in economic sociology and science and technology studies (STS) research examining the complex assemblages of epistemic devices - economic models, evaluation techniques, calculating instruments - that are needed to allow economic agents to make "rational" choices in market settings ${ }^{45}$ The list could be extended almost indefinitely, and nearly all of the essays in this volume have something to contribute to this conversation in one way or another.

Several of our essays explicitly feature economic and scientific thinking as a form of knowledge work. William Deringer, Martin Giraudeau, and Arunabh Ghosh focus on how calculation, a crucial technical practice common to science and capitalism, serves as a crucial site for the entanglement of both domains. ${ }^{46}$ All three challenge the assumption that calculation is simply a mechanical expression of a unitary capitalist or scientific rationality and instead show that calculative practices are creative and contested domains where actors experiment with different epistemologies and explore alternative futures. A key theme in the chapters is the way that the authority of calculators and calculative expertise is coproduced with visions of political-economic order. In his essay, Deringer sheds light on the culture and nature of exchange among British "men of science" between 1660 and 1720. He explains how two computational methods for dealing with annuities were presented as having mathematical ingenuity and financial utility in their promise to streamline many common financial transactions and why both were ultimately rendered obsolete for capitalist practice. Giraudeau characterizes a text written in 1800 by Irénée Du Pont de Nemours, used to raise funds for what was to become the Du Pont Corporation, as similar in kind to

\footnotetext{
${ }^{43}$ Timothy Mitchell, Rule of Experts: Egypt, Techno-politics, Modernity (Berkeley and Los Angeles, 2002), chap. 3; Carl Wennerlind, Casualties of Credit: The English Financial Revolution, 1620 1720 (Cambridge, Mass., 2011); Jonathan Levy, Freaks of Fortune: The Emerging World of Capitalism and Risk in America (Cambridge, Mass., 2012); Arwen Mohun, Risk: Negotiating Safety in American Society (Baltimore, 2012); Levy, "Accounting for Profit and the History of Capital," Crit. Hist. Stud. 1 (2014): 171-214.

${ }^{44}$ The literature on actuaries is especially extensive. See, e.g., Theodore M. Porter, Trust in Numbers: The Pursuit of Objectivity in Science and Public Life (Princeton, N.J., 1995), chap. 5; Timothy Alborn, Regulated Lives: Life Insurance and British Society, 1800-1914 (Toronto, 2009), chap. 4; Levy, Freaks of Fortune (cit. n. 43), chap. 3; Bouk, How Our Days Became Numbered (cit. n. 9). Another notable example, among many, is credit scoring: Martha Poon, "Scorecards as Devices for Consumer Credit: The Case of Fair, Isaac \& Company Incorporated," in "Market Devices," ed. Fabian Muniesa, Yuval Millo, and Michel Callon, suppl. 2, Sociol. Rev. 55 (2007): 284-306; Josh Lauer, "Making the Ledgers Talk: Customer Control and the Origins of Retail Data Mining, 1920-1940," in The Rise of Marketing and Market Research, ed. Helmut Berghoff. Philip Scranton, and Uwe Spiekermann (New York, 2012), 153-69.

${ }_{45}$ This literature is vast, but see esp. Daniel Beunza and David Stark, "Tools of the Trade: The Socio-Technology of Arbitrage in a Wall Street Trading Room," Indust. Corp. Change 13 (2004): 369-400; Donald MacKenzie, An Engine, Not a Camera: How Financial Models Shape Markets (Cambridge, Mass., 2006); Alex Preda, "Socio-Technical Agency in Financial Markets: The Case of the Stock Ticker," Soc. Stud. Sci. 36 (2006): 753-82; Muniesa, Millo, and Callon, "Market Devices" (cit. n. 44); Trevor Pinch and Richard Swedberg, eds. Living in a Material World: Economic Sociology Meets Science and Technology Studies (Cambridge, Mass., 2008); MacKenzie, Material Markets: How Economic Agents Are Constructed (Oxford, 2009); Canay Özden-Schilling, "The Infrastructure of Markets: From Electric Power to Electronic Data," Econ. Anthropol. 3 (2016): 68-80.

${ }^{46}$ William Deringer, "Compound Interest Corrected: The Imaginative Mathematics of the Financial Future in Early Modern England"; Martin Giraudeau, "Proving Future Profit: Business Plans as Demonstration Devices"; both in this volume; see also Ghosh, "Lies" (cit. n. 19).
} 
demonstration devices employed to assess profit and loss by natural philosophers at the time. Finally, Ghosh provides us with a Cold War case study that illustrates how and why socialist statistics emerged in the latter half of the twentieth century as a "social science" to serve as a powerful antidote to bourgeois liberal mathematical statistics. In doing so, he denaturalizes universalistic claims of liberal statistics that crucially rested on purportedly "pure" methods of probabilistic thinking in order to identify the ideological concerns behind them, including the desire on the part of capitalist states to increase their control and modernize statecraft, a goal that they shared with socialist nations.

Collecting and accumulation are forms of knowledge work and practice often positively associated with modern scientific inquiry and capitalism. Courtney Fullilove, Julia Fein, and Sarah Milov turn our attention to different forms of collecting objects - biomatter, natural history specimens, and epidemiological data — and consider how such knowledge work functions to make or unmake commodities in particular political economies. ${ }^{47}$ Fullilove's essay features contemporary bioprospecting, the collecting of pest-resistant cereal endophytes for capitalist purposes of profit-oriented international gene banks, outlining the emerging characteristics of the twenty-firstcentury political economy that underlies the practice and informs what biota are treated as a commodity and why, as well as who benefits and loses. Fein's essay examines how material - in this case, "scientific crude," or natural history specimens - is collected for the purposes of turning it into a global commodity in, surprisingly, a communist command economy. Examining the collection of such "crude" from the Siberian periphery during Stalin's first Five-Year Plan (1928-32), Fein specifically illustrates how the socialist state mobilized the collection of such material originally to sell it on the global market until Moscow ultimately shifted its policy toward requisitioning the material away from the Siberian periphery to the center as a form of national heritage. Milov's essay turns our attention to the unexpected transnational significance of data collection on wives of Japanese smokers. She shows how American tobacco that flowed into Japanese markets and lungs served as the basis of Japanese epidemiological data, which, in turn, traveled back to the United States and was used by antitobacco grassroots activists as evidence for public smoking bans against the interests of big tobacco.

If calculation, classification, and collection are relatively iconic forms of knowledge work for scientific and capitalist endeavors, other contributors pay attention to ways of knowing and acting that are not usually associated with the two domains. Eugenia Lean and Hallam Stevens draw our attention to the act of copying, conventionally reviled as a problematic practice obstructing innovation and free market dynamics in more hagiographic accounts of science and capitalism. ${ }^{48}$ Rethinking the place and value of copying in scientific and capitalist innovation, both Lean and Stevens draw on case studies from China, which has been targeted for engaging in exceptionally unethical copying since the late nineteenth century. By examining early twentieth-century international disputes over alleged Chinese counterfeiting of Bur-

\footnotetext{
47 Courtney Fullilove, "Microbiology and the Imperatives of Capital in International AgroBiodiversity Preservation," in this volume; Fein, "Scientific Crude" (cit. n. 19); Sarah Milov, "Smoke Ring: From American Tobacco to Japanese Data," in this volume.

${ }^{48}$ Eugenia Lean, "Making the Chinese Copycat: Trademarks and Recipes in Early TwentiethCentury Global Science and Capitalism," in this volume; Stevens, "Starting" (cit. n. 23).
} 
roughs, Wellcome's popular vanishing cream, Hazeline Snow, Lean shows how copying the product's trademarks and adaptation of its recipes proved crucial in helping Chinese merchants innovate their own products and compete globally in a competitive pharmaceutical market. To stem this rising tide of Chinese manufacturing power, Burroughs, Wellcome and other pharmaceutical companies aggressively promoted an emerging intellectual property (IP) regime, identified Chinese copying as unethical, and pursued alleged copycats. Stevens moves us forward in time to focus on how the Beijing Genomics Institute (BGI), a DNA-sequencing research institute in contemporary Shenzhen, engages in acts of adaptation to establish itself as a highly creative, hybrid corporation that is competitive worldwide. Both contend that copying and innovation have not been mutually exclusive in modern science and capitalism and show that while the Chinese actors they consider are savvy in their acts of adaptation, they have never been singular in their copy work, because copying and adaptation have taken place in all corners of the modern and contemporary world.

The laborious and unglamorous act of maintenance is another form of knowledge work that has often been given short shrift in accounts of science and capitalism that focus on revolutionary leaps in scientific invention and capitalist innovation. Here, two of our contributors - Emily Pawley and David Singerman - focus their attention on the knowledge and drudgery involved in the day-to-day and season-to-season processes of engineering the reproductive capacities of sheep and the technical upkeep of sugar machinery in capitalist industries of the eighteenth and nineteenth centuries. ${ }^{49}$ Pawley's account takes us to the fields of mid-eighteenth-century Britain, at a moment when the onset of new forms of "agricultural capitalism" was dramatically transforming the way food was produced and eaten. Her study examines how agricultural experts and practicing farmers built up a new body of natural knowledge about livestock, aimed at producing tender bodies available at all times of the year to meet the increasingly voracious demands of an emerging consumer market in meat. At the center of this biological project were a battery of new techniques, including feeding regimens and the design of natural landscapes, intended to direct and manage animals' sexual desires and reform those occasionally recalcitrant beings into agreeable producers of new animal bodies. Singerman's "Sugar Machines" illustrates the various material parts and paper devices that Scottish engineers utilized in order to maintain and manage temperamental machines that were shipped to far-flung environments in the Caribbean as the production of sugar had become increasingly global by the nineteenth century. If scholars interested in global circulation of commodities and knowledge have focused on the epistemic work that goes into creating standardized, mobile units, Singerman shows that such standardized circuits were only possible because of the maintenance work done by technicians and engineers bearing highly specialized and often tacit forms of technical knowledge that defied standardization.

Given the important contributions historians of science have made to the study of thinking and knowing in practice, the recent surge of attention to the epistemic dimensions of capitalism offers an obvious opportunity for further collaboration. In fact, historians of science and STS scholars have been key contributors to many of

\footnotetext{
${ }^{49}$ Emily Pawley, "Feeding Desire: Generative Environments, Meat Markets, and the Management of Sheep Intercourse in Great Britain, 1700-1750"; David Singerman, "Sugar Machines and the Fragile Infrastructure of Commodities in the Nineteenth Century," both in this volume.
} 
the key trends listed above - from the study of technical devices in shaping markets and "futures" to agnotology. Yet this shared attention to the epistemic dimensions of capitalism does not imply a desire to see the history of capitalism become a purely intellectual history, or for scholars to neglect the material dimensions of life under capitalism. One of the reasons historians of science can offer an especially useful perspective on economies past is precisely that they are used to reckoning yet another entanglement, namely, the way "epistemic things" and material objects are constantly commingled. One of the most provocative examples is the argument by STS scholars like Michel Callon and Donald MacKenzie that economic models play a crucial role in shaping how markets are constructed, the decisions economic actors can make, and what forms of economic action are rational. At its strongest, this argument about the "performativity" of economic models suggests that certain claims about how the economic world operates, like the Black-Scholes-Merton model for pricing stock options, or "Moore's law" regarding the development of the semiconductor industry, may act as a self-fulfilling prophecy, meaning they have the power to reshape economic phenomena in their own image. ${ }^{50}$ While this performativity thesis has generated much debate, it offers a vital reminder that, to borrow a different idiom, economic order is coproduced with economic knowledge - and an invitation to historians of science to help explain such historical entanglements. ${ }^{51}$

Thus, this volume does not only seek to treat knowledge work as a practice, a form of intellectual labor. Our aim is also to lay bare the deep entanglement between words and things, theory and reality, epistemology and ontology. Indeed, several essays in this volume even go so far as to argue that cognitive practices can lead to the creation of new entities and relationships in the world. To highlight this point and make it explicit, we have chosen to group some of the essays into a section on "Entangled Ontologies." 52 For example, Lee Vinsel's essay on auto regulation shows how a group of industrial psychologists created a lucrative niche from which to augment their professional power by arguing that a new technology, the automobile, led to the creation of a new kind of person, the accident-prone driver. Similarly, Victoria Lee tracks the way science as an institution of epistemic authority and the microbe as an object of knowledge coproduced one another in late Meiji Japan. Paul Lucier shows how the involvement of geologists in the practice of what he provocatively calls "Comstock Capitalism" led to the consolidation of a new, material entity: the single, continuous,

\footnotetext{
${ }^{50}$ Michel Callon, "Introduction: The Embeddedness of Economic Markets in Economics," in The Laws of the Markets, ed. Michel Callon (Oxford, 1998), 1-57; MacKenzie, Engine (cit. n. 45); Donald MacKenzie, Fabien Muniesa, and Lucia Siu, eds., Do Economists Make Markets? On the Performativity of Economics (Princeton, N.J., 2007), esp. the chapter by Callon, "What Does It Mean to Say Economics Is Performative?," 311-57; Peter Miller and Ted O'Leary, "Mediating Instruments and Making Markets: Capital Budgeting, Science and the Economy," Account. Org. Soc. 32 (2007): 701-34; Franck Cochoy, Martin Giraudeau, and Liz McFall, "Performativity, Economics, and Politics: An Overview," J. Cult. Econ. 3 (2010): 139-46. For a notable critique, see Philip Mirowski and Edward Nik-Khah, "Markets Made Flesh: Performativity, and a Problem in Science Studies, Augmented with Consideration of the FCC Auctions," in MacKenzie, Muniesa, and Siu, Do Economists Make Markets?, 190-224.

${ }^{51}$ Sheila Jasanoff, "The Idiom of Co-Production," in States of Knowledge: The Co-Production of Science and Social Order, ed. Sheila Jasanoff (London, 2004), 1-12.

${ }^{52}$ Victoria Lee, "The Microbial Production of Expertise in Meiji Japan”; Lee Vinsel, "'Safe Driving Depends on the Man at the Wheel': Psychologists and the Subject of Auto Safety, 1920-55"; Paul Lucier, "Comstock Capitalism: The Law, the Lode, and the Science"; Lukas Rieppel, "Organizing the Marketplace," all in this volume; Fein, "Scientific Crude"” (cit. n. 19).
} 
extremely valuable, and thus hotly contested "Comstock Lode." Finally, Fein shows how a new kind of commodity — scientific crude - was created in response to Stalin's first Five-Year Plan during the early twentieth century, whereas Lukas Rieppel argues that as a new science of life came into being around the turn of the nineteenth century, organization was refashioned from a feature or property of living beings to a thing in itself - the organism - whose functional integration subsequently came to serve as a model for business organization, especially in the context of large, multidivisional corporate firms. Several other essays in the volume that are not explicitly grouped into this category also discuss the creation of new entities that have emerged with the modern entanglement of science and capitalism. All share the concern of shedding light on how the imperatives of science and capitalism resulted in the articulation of new social roles (the accident-prone driver, the Chinese copycat, the scientist) and objects of knowledge (the microbe, socialist statistics, organization) that, in turn, profoundly shaped concrete material practices as well as political and economic relationships, both local and global.

\section{CIRCUITS OF EXCHANGE}

Our third scholarly intervention involves adopting a global approach to the study of the entanglement of science and capitalism from the early modern period to the twenty-first century. We are indebted to developments in both the history of capitalism and the history of science fields. Historians of capitalism have long adopted a global purview, even as some have remained more comparative in their approach. ${ }^{53}$ But, as noted above, some recent historians of capitalism are moving beyond comparative methods by paying attention to what were often violent transnational and global relations in the production of commodities like cotton. ${ }^{54}$ Similarly, the history of science has increasingly adopted a more global approach in seeking to unravel triumphalist narratives that see the scientific and industrial revolutions as somehow unique to the West, or as automatically desirable and inexorable. If revisionist historians of capitalism have helpfully shed light on how early modern circuits of silver and modern commodities have flowed in multiple directions, historians of science have been particularly effective in attending to the global movement of knowledge. Some have engaged in more theoretically oriented inquiries to conduct a sustained conversation about how fundamentally interconnected the world has been in the making of modern science. Postcolonial scholars of science and medicine, for example, have been among the most critically engaged in articulating the moral imperative to

\footnotetext{
${ }^{53}$ The comparative approach is especially clear in the "varieties of capitalism" literature. See, e.g., John R. Bowman, Capitalisms Compared: Welfare, Work, and Business (Los Angeles, 2014); Barry Stewart Clark, The Evolution of Economic Systems: Varieties of Capitalism in the Global Economy (New York, 2016); David Coates, ed., Varieties of Capitalism, Varieties of Approaches (New York, 2005); Peter A. Hall and David W. Soskice, eds., Varieties of Capitalism: The Institutional Foundations of Comparative Advantage (Oxford, 2001); David Hundt and Jitendra Uttam, Varieties of Capitalism in Asia: Bevond the Developmental State (London, 2017); Martha Prevezer, Varieties of Capitalism in Historv. Transition and Emergence: New Perspectives on Institutional Development (New York, 2017)

There have been criticisms of Beckert's important work, however. For a Marxist-inflected critique that demands a more explicit theorization of valuation in the discussion of capitalism, see Aaron G. Jakes and Ahmad Shokr, "Finding Value in Empire of Cotton," Crit. Hist. Stud. 4 (2017): 107-36. In addition, it has also been noted that Beckert fails to address the ecological implications of cotton emerging as a quintessential commodity in war capitalism.
} 
challenge Eurocentric narratives that posit how modern science emerged singularly in the West and was subsequently exported abroad, rendering it challenging to even distinguish "Western" from "non-Western" science. ${ }^{55}$ Warwick Anderson insists on "a critical engagement with the present effects ... of centuries of "European expansion" " to decenter "conventional accounts of so-called 'global' technoscience, revealing and complicating the durable dichotomies [of global/local, first world/third world, Western/indigenous, and big science/small science], produced under colonial regimes, which underpin many of its practices and hegemonic claims. ${ }^{.56}$

Explorations into the motifs of circulation, movement, and exchange have taken up such a task by providing a powerful framework from which to complicate such durable dichotomies. Because knowledge only becomes recognized as such once it has been widely shared within a community of knowing subjects, circulation is now widely seen to be part and parcel of how knowledge is made, not just an afterthought. The importance of this insight can hardly be overstated, particularly given the methodological space it has opened for writing a global history of science that does not valorize the importance of Europe and North America over the rest of the world. There is also now considerable recognition that knowledge about the natural world emerged through encounters and exchanges between people from all parts of the globe, not just between Europe and the "rest." ${ }^{57}$ Finally, related efforts have focused on the way global brokers or mediators facilitated the circulation of knowledge, often in ways that move beyond a strict metropole-colony axis. ${ }^{58}$ Rather than privileging Western actors as global agents and dismissing non-Western actors as "local," "indigenous," or somehow particularized ${ }^{59}$ these histories of science emphasize the way gobetweens have often been more "cosmopolitan" than counterparts who remained in the metropole. ${ }^{60}$

\footnotetext{
${ }^{55}$ For one of the best-known and most controversial proponents of the idea that modern science was disseminated to non-Western parts of the world and that non-Western societies were merely passive receptors of scientific knowledge, see Basalla, "Spread of Western Science" (cit. n. 8).

${ }^{56}$ Warwick Anderson, "Introduction: Postcolonial Technoscience," Soc. Stud. Sci. 32 (2002): 64348 , on 644 .

${ }^{57}$ Daniela Bleichmar, Visible Empire: Botanical Expeditions and Visual Culture in the Hispanic Enlightenment (Chicago, 2012); Antonio Barrera-Osorio, Experiencing Nature: The Spanish American Empire and the Early Scientific Revolution (Austin, Tex., 2006); Neil Safier, Measuring the New World: Enlightenment Science and South America (Chicago, 2008); Bernard V. Lightman et al., eds., The Circulation of Knowledge between Britain, India, and China: The Early-Modern World to the Twentieth Century (Leiden, 2013).

${ }^{58}$ Raj, Relocating Modern Science (cit. n. 12); Simon Schaffer, Lissa Roberts, Kapil Raj, and James Delbourgo, eds., The Brokered World: Go-Betweens and Global Intelligence, 1770-1820 (Sagamore Beach, Mass., 2009).

${ }_{59}$ Some work that falls more squarely in the postcolonial framework of exploring the transmission of knowledge from the metropole to the colony has still tended to treat Western actors as the "global" actor, and the non-Western agents as the "local," and particularized, or "indigenous" agent.

${ }^{60}$ Translators and diplomats, Chinese and Naxi guides to British botanists, and native informers to colonial scientists in early twentieth-century Africa are but a few examples of figures who participated in transnational circuits of knowledge and materials, actively helping to constitute modern science. On translators and diplomats, see Raj, Relocating Modern Science (cit. n. 12); Marwa Elshakry, Reading Darwin in Arabic, 1860-1950 (Chicago, 2013). On Chinese and Naxi guides to imperialist botanists, see Fa-ti Fan, British Naturalists in Qing China: Science, Empire, and Cultural Encounter (Cambridge, Mass., 2004); and Erik Mueggler, The Paper Road: Archive and Experience in the Botanical Exploration of West China and Tibet (Berkeley and Los Angeles, 2011), respectively. On African informers to colonial naturalists, see Nancy Jacobs, Birders of Africa: History of a Network (New Haven, Conn., 2016); Helen Tilley, Africa as a Living Laboratory: Empire, Development, and the Problem of Scientific Knowledge, 1870-1950 (Chicago, 2011). In this light, Jesuits might be seen not as
} 
With the term "broker" being so intimately associated with economic exchange and circulation, it strikes us that our interest in the entangled history of science and capitalism would similarly benefit by being approached as a story of linkages that emphasizes practices of brokerage and translation, points of convergence, and globally circulating networks of expertise and material, and that eschews the dichotomies of "global/local," "West/rest," and others. Indeed, several of our contributors approach their case studies in this manner, focusing on points of convergence and brokers that have facilitated the global circulation of both science and capitalism in the period spanning the nineteenth to twenty-first centuries. Singerman's "Sugar Machines" looks at one of the quintessential commodities of modern capitalism - sugarand recovers the key historical actors - a coterie of Glasgow-based engineers - and their ceaseless intellectual and physical labor that went into maintaining the fragile material infrastructure of nineteenth-century transnational sugar production. ${ }^{61}$ Ghosh, focusing on a much more recent era, demonstrates how Soviet theoreticians and statisticians were global actors who helped circulate socialist statistics to other parts of the emerging socialist world, including China. ${ }^{62}$ This transnational circuit of knowledge producers generated a form of statistics that was not somehow derivative of authentic capitalist statistics but emerged as a calculative culture of the socialist world that made sense within the geopolitical context of the Cold War. In his study of BGI, Stevens sheds light on how this hybrid research center was not merely an imitation of the Western factory, engaged in rampant copying (as Western journalists regularly charge), but functions as a "broker" of sorts. He argues that BGI "performs" shanzhai, a do-ityourself mode of innovation that reflects Shenzhen's biotech and manufacturing culture more generally and relies on the ability to copy and adapt in order to compete effectively on a global scale. ${ }^{63}$

While the global circulation of knowledge as one among many economically valuable commodities offers a highly suggestive way to bring the histories of science and capitalism into dialogue, we also see a number of dangers that emerge from the recent enthusiasm for "knowledge in transit," as James Secord has evocatively described it. ${ }^{64}$ Precisely because the motif of circulation is so closely connected to both classical and neoliberal models of the way value is generated, it behooves scholars to question more carefully the conditions in which knowledge is made to travel. Doing so not only means taking seriously those cases in which knowledge and things resolutely stay put, refusing to partake in global circuits of intellectual and economic exchange. It also requires that we take seriously the asymmetries in epistemic, economic, and technical power that shape the way knowledge and commodities alike can be, and have been, mobilized. For that reason, we would be remiss if we were to restrict ourselves to the logic of circulation alone. The way knowledge and other resources are accumulated is decisive as well, producing asymmetries and inequalities with clear

\footnotetext{
Western missionaries transmitting religion and science from the European metropole to other parts of the world in the early modern period, but as a cosmopolitan cadre of go-betweens who shared information among a variety of empires as they traveled across the globe. On this point, see Laura Hostetler, Qing Colonial Enterprise: Ethnography and Cartography in Early Modern China (Chicago, 2001).

${ }^{61}$ Singerman, "Sugar Machines" (cit. n. 49).

${ }^{62}$ Ghosh, "Lies" (cit. n. 19).

63 Stevens, "Starting" (cit. n. 23).

${ }^{64}$ Secord, "Knowledge in Transit" (cit. n. 12).
} 
consequences for what can be known and who knows it. Given these considerations, we advocate taking our cues from scholars who emphasize the arduous labor, coercion, expropriation, and at times even violence that histories of the way knowledge circulates often belie. In particular, while we agree that a claim must be widely shared in the community to be seen as legitimate, the constitution of that very community is achieved by creating boundaries and erecting barriers to exclude those who are not seen to have a proper place in the group. And while we acknowledge that there can be no doubt that efforts to promote movement and communication play an indispensable role in the history of science and capitalism, these efforts always operate in combination with concordant attempts to control, manage, and, at times, explicitly arrest the movement of objects, ideas, and people. ${ }^{65}$

Several contributions here are explicit in their consideration not only of global circulation but also of instances when movement is obstructed and circulation is arrested, when exclusive communities and boundaries are erected. Lean's essay, for example, explores how the emerging early twentieth-century IP regime of trademark infringement sought to obstruct the circulation of manufacturing knowledge to alleged Chinese copycats in order to improve global market conditions for British pharmaceutical corporations. Fein's essay identifies the process by which Siberian "scientific crude," or natural history specimens, was decommodified in the Soviet Union during the Stalinist period. This was not simply because of the ideological imperatives of a communist command economy, but more because Moscow, which was invested in securing global exports at the time, ultimately came to value this particular material more as national patrimony to be stocked domestically than as an export commodity to be sold abroad. Sarah Milov's contribution sheds light on how the collection of data from Japanese smokers of American tobacco unexpectedly served to underpin a grassroots movement against American big tobacco in the second half of the twentieth century. And Fullilove's piece demonstrates how contemporary international gene banks, which rely on botanic and Linnean classification systems to commoditize biomatter, are now challenged and, indeed, being rendered obsolete by emerging biomatter commodities, such as the fungal endophyte, which feature the genome as the key to their value. By historicizing the instances when the circulation of scientific knowledge or capital has been obstructed, halted, or somehow altered, these essays delve into why global flows and stoppages occurred and what was at stake when they did. ${ }^{66}$

Finally, it should be noted that, even though this volume eschews any "origins" narrative, it does seek to identify the historically specific conditions under which science and capitalism emerged as powerful institutions and ideological regimes by the nineteenth century. In the early modern period, the pursuit of profit in rational, calculative ways, along with empirical ways of knowing the natural world, did not exist solely in the West and could be found in many parts of the world. ${ }^{67}$ Yet, even as we

\footnotetext{
${ }^{65}$ See Warwick Anderson, "Making Global Health History: The Postcolonial Worldliness of Biomedicine," Soc. Hist. Med. 27 (2014): 93-113.

${ }^{66}$ Lean, "Making the Chinese Copycat" (cit. n. 48); Fullilove, "Microbiology"; Milov, "Smoke Ring" (both cit. n. 47).

${ }^{67}$ These various forms of empiricism and pursuits of profit did not automatically result in the development of modern science and capitalism and must be studied on their own terms. Revisionist historians of science have unearthed "non-Western" systems of natural, technological, and healing knowledge to demonstrate how rich ways of knowing that appear to mirror the empiricism of Western
} 
recognize the historical existence of multiple forms of empiricism, we are interested in historicizing the specific conditions of the eighteenth and nineteenth centuriesincluding, crucially, imperial encounters and global exchange - under which specific forms of empiricism did develop to justify and underlie practices of pursuing profit and producing knowledge through extractive and often violent means. A system of capitalist accumulation in which profits were pursued with a calculated acquisitiveness that was predicated upon key social processes (including ways to manage labor and define relations of production, extract material resources, and rearrange geopolitical dynamics) emerged to guarantee ever-cheaper costs of industrial capital. So, too, did conditions that enabled scientific knowledge production that claimed to be value neutral and free of economic and political implication, even as that knowledge was in fact dependent upon extractive approaches to data collection, called for a particular exploitative relationship toward the natural world and was often inextricably linked with capital or state power. Taken together, these developments in science and capitalism came to radically reshape economic and epistemological practice around the world, reconfigure relations of production, labor regimes, and geopolitical dynamics, as well as usher in new ways of understanding and interacting with the natural world.

To better understand the historically specific conditions under which the nineteenthcentury coproduction of science and capitalism occurred, we include several European case studies from the early modern period. Again, not seeking the "origins" of science or capitalism, these pieces seek to help decenter any origins narrative from within by refusing a teleological perspective and attending to the historically contingent circumstances that informed economic and epistemological practices - the knowledge work - that did emerge. Some of these practices documented in these essays were retrospectively deemed the "roots" of science and capitalism. Some were not. Deringer's and Giraudeau's contributions, for instance, both recover epistemic practices of calculation that did not inexorably lead to capitalism and science. In showcasing multiple ways that an early modern financier might have calculated futures, Deringer, for example, uncovers methods of the early modern era on their own terms that were rendered obsolete when compound-interest discounting became "blackboxed" in modern capitalist practices. In an investigation into how market demand for lamb during the off-season engendered new breeding techniques and ways to shape the environment, Pawley similarly avoids a straightforward story of rationality or pure market demand for mid-eighteenth-century British agricultural capitalism. Instead, she shows us how this new system engendered a host of actors - botanists, physicians, professional feeders - invested in maintaining a system that rested on

technoscience did not inevitably lead to the rise of modern science, but proved productive, generative, and instrumental for a host of other institutional and ideological purposes. For examples in the case of early modern China, see Benjamin Elman, On Their Own Terms: Science in China, 1550-1900 (Cambridge, Mass., 2005), who documents how the rise of empirical studies in Qing China, where philological and evidentiary knowledge was applied to knowing the cosmos for purposes of moral cultivation and imperial politics. Far from a "failure" or missed opportunity on the part of the Qing to develop an exact Chinese analogue to European capitalism or Western science, this application of precise knowledge for purposes of moral and political power made perfect sense within the institutional and cultural context of a vibrant early modern empire. For another study that examines the production of scientific - in particular, cartographic and ethnographic - knowledge in the context of the Qing empire in its own right (in contrast to the "empire" of "science and empire" studies, which is implicitly always assumed to be Western imperialism), see Hostetler, Qing Colonial Enterprise (cit. n. 60). 
what might be seen as an illogical practice of manipulating what were natural rhythms in sheep reproduction. If these three essays examine the eighteenth century, the remaining contributors examine science and capitalism from around the world during the nineteenth and twentieth centuries. Together, the pieces from the modern period until today document how the complex entanglement of science and capitalism was hardly a development that simply moved from the West to the rest after a point of purported divergence. Instead, this entanglement has continuously evolved and remade itself via global and transnational connections and obstructions. And it has done so in a variety of locations and in a variety of ways. 